\title{
Obstetrical nursing and health education: contributions to the experience of process of parturition
}

\author{
Enfermagem obstétrica e educação em saúde: contribuições para vivência do processo de \\ parturição
}

Jacqueline Silveira de Quadros ${ }^{1}$, Thamiza Laureany da Rosa dos Reis ${ }^{1}$, Juliana Silveira Colomé2

Objective: to understand the contributions of obstetrical nursing to health education activities aimed at the parturition process. Methods: qualitative research conducted with ten hospitalized puerperal women who had vaginal delivery in a maternity ward. Results: two categories emerged from the data of this research: Weaknesses of prenatal care for pregnant women and The obstetrical nurse as potentiator of humanized care. Conclusion: obstetrical nursing, through educational work, strives to promote a reframing of the process of parturition, rescuing parturition as a physiological process, and emphasizing the use of natural resources in the evolution of labor and delivery.

Descriptors: Health Education; Obstetric Nursing; Women's Health.

Objetivo: compreender as contribuições da enfermagem obstétrica para as ações de educação em saúde voltadas ao processo de parturição. Métodos: pesquisa qualitativa desenvolvida com dez puérperas internadas, que tiveram parto vaginal em uma maternidade. Resultados: dos dados desta pesquisa, emergiram duas categorias: Fragilidades da assistência pré-natal à mulher/gestante e 0 enfermeiro obstetra como potencializador do cuidado humanizado. Conclusão: a enfermagem obstétrica, por meio do trabalho educativo, empenha-se em promover uma ressignificação do parto, resgatando a parturição como um processo fisiológico, e ressaltando o uso de meios naturais na evolução do trabalho de parto.

Descritores: Educação em Saúde; Enfermagem Obstétrica; Saúde da Mulher.

\footnotetext{
${ }^{1}$ Universidade Federal de Santa Maria. Santa Maria, RS, Brazil.

${ }^{2}$ Centro Universitário Franciscano. Santa Maria, RS, Brazil. 


\section{Introduction}

The experience of pregnancy is a unique and unforgettable event in the life of every woman and of her family, but it can also be a time of anxiety and distress. In this sense, health education practices should help women to understand pregnancy and childbirth as physiological events that can cause physical and emotional changes. Thus, it is the role of health professionals who provide prenatal care to guide women and their families, as well as clarify doubts, which should contribute to autonomy of care $^{(1)}$.

Prenatal consultation is an important tool for the hosting and for developing a link between the professional and the pregnant woman. It is the moment when the nurse has clinical knowledge, based on scientific evidence, and the opportunity to identify and exploit the uniqueness of each woman. As the link is built, needs are perceived, the capabilities and/or limitations of the woman in dealing with the gestational and birth process. Thus, the work of nurses must provide welfare and safety ${ }^{(1)}$.

Health education is defined as a set of knowledge and practices to promote health. It is a valuable strategy to associate the popular knowledge to the scientific knowledge. This is done through the involvement of the individual in his context, reflecting on his behalf and of his community. In addition, educational activities can encourage the empowerment and autonomy of women in relation to their body, allowing them to actively experience the process of parturition ${ }^{(2-3)}$.

However, such practices require an open and humane attitude of all health professionals in a changing perspective of obstetric practice. In this sense, obstetrical nurses have shown willingness to promote actions of humanization and have assisted in the eliminating the medical model of childbirth, working in management, teaching and care. This professional performs nursing care to woman during pregnancy, childbirth, and postpartum, and to the newborn. The nurse also monitors the progress of labor, the use of non-pharmacological methods for pain relief, the execution and obstetric care in cases of emergency and the assistance to the delivery with obstetrical risk, besides following the child up 24 months of life ${ }^{(3-4)}$.

However, fear of parturition and of pain is still passed from generation to generation and interfere with the development of pre-delivery and delivery. It is known that health education contributes to the demystification of suffering during the parturition, showing to women that it is possible to experience it in an active and participative manner, deciding on their own bodies and connecting with their instinct to give birth. Consequently, these women transmit what they have learned by creating a new tradition of feminine wisdom, helping other women to regain their autonomy in the process of labor and birth ${ }^{(5-6)}$. Thus, health education can serve to potentiate the care because it can generate changes in the current obstetrical care model, which has high rates of unnecessary interventions, as well as maternal and neonatal morbidity and mortality in the country.

Caesarean sections contribute to this situation. These have become the most common mode of delivery, reaching $85.0 \%$ of births in private health services, and $40.0 \%$ in the public health system - the World Health Organization recommendation is $15.0 \%$. Cesarean section, when performed under indications, is essential for maternal and child health, but when carried out without the correct indication may involve increased risk of complications. It is noteworthy that many women chose cesarean section due to the type of assistance mostly provided to vaginal delivery in the country ${ }^{(7)}$.

Given the above, the question that raises is: what are the contributions of obstetrical nursing to health education activities aimed at the process of parturition? The objective of the study was to understand the contributions of obstetrical nursing to health education activities aimed at the process of parturition. 


\section{Methods}

Qualitative research that considers the environment as directsource of data and the researcher as a key tool, wherein the process is the main focus of the approach, and not the result or product ${ }^{(8)}$. The research was conducted in the Maternity ward of the Hospital Home of Health in Santa Maria, Brazil. This is a reference site for delivery with usual risk of users of the Unified Health System. This institution holds practices of residence in Obstetric Nursing of the Franciscan University Center, noting that this course, besides pioneer, is the only one active in the state.

Ten hospitalized mothers who had vaginal delivery in that maternity participated in this study, thus constituting an intentional sample, that is, when participants are selected because they represent the relevant characteristics of the study population ${ }^{(9)}$. Inclusion criteria were: primiparous mothers who underwent prenatal care in Basic Health Units of Santa Maria, assisted by physicians, nurses and/or residents in obstetrical nursing. Exclusion criteria were: multiparous mothers because they have had other experiences of delivery, and women who did not receive prenatal care in Basic Health Units of Santa Maria. The period of the study was from August 2014 to February 2015.

Data collection was carried out through semistructured interviews held in private places with the presence of the researcher and the participants individually. The interview was recorded and transcribed with permission of the interviewees. Therefore, the mothers were invited to reflect and to answer some questions: During prenatal care, did you participated in groups of pregnant women and/ or discussions in the waiting room? What issues were discussed? During prenatal consultations, guidelines were given to you about labor and/or delivery? Which guidelines? Did you have knowledge on the law that assures the right for the presence of a companion of your choice during labor, delivery and postpartum? Who gave you advice? Did you miss any information that would have helped you in the development of birth? Which information? During prenatal consultations, were guidelines about nonpharmacological methods for pain relief and their use during labor (ambulation, choice of positions, use of Swiss ball, etc.) were provided to you?

Data were submitted to thematic content analysis, which is composed of three stages: the first consisted of a frequency to identify the main strengths and weaknesses in the assistance provided to the respondents; then the content that identified the categories that emerged from the collected data were analyzed; finally, categories were interpreted to understand the experience of women/pregnant women based on the researcher's knowledge related to the purpose of the study. Thus, it was possible to adequately analyze the answers, in order to organize them by groups ${ }^{(8)}$.

The study complied with the formal requirements contained in the national and international regulatory standards of research involving human beings.

\section{Results}

The women participating in the study were aged between 16 and 32 years, five were single, three married and two were divorced. However, all were in a relationship with a partner in the period of the interview. Regarding education, three have completed high school, four did not finish high school and three completed elementary school. In relation to previous prenatal activities, three of them had 11 prenatal consultations, two had eight consultations, two had six visits, one had five consultations and one had four consultations.

\section{Weaknesses of prenatal care for pregnant women}

Some gaps in educational activities during prenatal care were observed, as these were present in the speeches of the participants: My prenatal care was very basic, 
because the doctor was very simple, he did not provide deep information on the subject, he did not like to look too much in the face of the patient. He is a gynecologist and he did not pass much information. I was the one who went after information. I was collecting information from one and from other, I went to internet I was then gaining knowledge on how it was going to be (Int. 05). During prenatal I did not receive any information from the physician, it was the basics. I went to the consultations, checked the pressure, measures (uterine height), I listened to the little heart, the basics (Int. 02).

Another point asked to the mothers in the study was about the knowledge they had about the right for the presence of a companion of their choice during labor, delivery and postpartum care. Most of them reported not having received any knowledge about the law that establishes this right: No, I did not even know. The only thing I was informed was regarding the hospital. An acquaintance of mine had her baby in a hospital ...2 months ago, and she could not have a companion, then I had this fear. But I knew here they use to give this [the presence of the companion], then I came here (Int. 08). During consultations they did not tell me anything, I thought I would be alone. But I saw a sign in the hallway [Law 11,108/2005] that my mother could stay with me (Int. 04).

When participants were asked about the lack of any information during the prenatal, we noticed some weaknesses in health education and the lack of commitment of the professionals who cared for the pregnant women, attitudes that usually potentiate fears and anxieties about vaginal delivery: There was absolutely no information from the doctor. I preparing especially in the last month. To prepare myself psychologically because I knew it would come to such a pain, but I did not know how it would be like. For example, the issue of the bath, I was 20 minutes in the bath and it helped me a lot, the pain was bearable, I was relieved (Int.03). I think the touch examination was not done, they [prenatal professionals] did not do. At the time of delivery, they did not explain anything to me (Int. 10). They do not tell me anything about the childbirth. I was very afraid from what my friends told me, they tell us, each one says something, but here in the hospital, they were explaining to me (Int. 07).

\section{The obstetric nurse as potentiator of humanized care}

In the Brazilian context, a movement of change in current obstetrical model has taken place. Some scenarios were occupied by obstetric nurses who sought to offer favorable conditions for a less interventionist assistance. When the women in the study were asked if, during prenatal care, they had received information about labor and delivery, we realize that those who underwent prenatal care with nurses and/or residents in obstetrical nursing had greater understanding of the subject: Yes, to walk would be good, would help to dilate [cervical dilatation]. The resident explained to me how the contraction would be like and the intensity, when I had to come to the hospital... It was good to know. Without information it would be difficult, I would not know right (Int. 05). I received [guidelines] in a group of pregnant women... They [nurses and/or residents] taught us, they even showed us videos, about how was the birth, for we to have an idea. They told us that labor would be normal, we would feel pain, but we would be helped and would have all the support from the nurses. And also about what was contraction (Int. 09). All the information I received was beneficial to me and I tried to put in practice as much as I could, this information I received. It was wonderful (Int. 01).

The participants of the survey were also asked about the guidelines they received during prenatal consultations about non-pharmacological methods for pain relief and their use during labor; once again, we realize the importance of nurses and/or residents in obstetrical nursing in the instructions given during prenatal care: When I got here [maternity] I knew I was going to use the ball, I knew about the warm bath and even the position [squatting position] for the baby to come down faster. This they explained me [nurses and/or residents] during prenatal, and it was faster for dilatation (Int. 02). They helped me [nurses and/or residents] enough. When I walked I dilated [cervical dilatation] a bit more and at bath I relaxed and that helped. The ball also helped 
me a lot, but that information I found here in the hospital (Int. 06). Last month I came here in the maternity to seek information, to see if everything was alright with the baby, because I just did exams in the second quarter as he [prenatal professional] did not ask anything, he said it was not necessary. But with the group of nurses, I was even saying this to my family, I found them very good. Both the doctor and also nurse were all the time explaining me. This thing about massage, I had never heard about it, only here when I came to evaluation [obstetric evaluation] (Int. 07).

\section{Discussion}

The f study to be performed only with mothers was considered a limitation, since it is believed that it is important to listen to all actors involved in the various segments of care to women during the process of delivery. Furthermore, the study was also carried out in a teaching hospital and the participants were all users of the Unified Health System, and this makes it questionable the degree of generalization for the entire population.

As possible contributions of the results for the assistance, the study showed the need for training and the relevance of the performance of obstetrical nurses. These professionals strive to promote the humanization of care and the empowerment of women in relation to their body, using educational activities as a tool to promote childbirth reframing, rescuing parturition as a physiological process, using natural means in the evolution of labor and delivery.

During prenatal care, guidelines were not a prioritized aspect. Poor adherence to carry out health education was observed. Some professionals are used to working in a paternalistic way, and for these, it is a challenge to introduce educational activities in their practice. It is noteworthy education is an efficient method, besides it meets the needs of women, clarifying their doubts, promoting healthy lifestyles and thereby aiming to the welfare of the pregnant woman and her family. The poor adherence of professionals to this strategy can be explained to the fact that this requires daily work and require persistence, so that actual results can be seen. However, it is clear that nurses are assuming an important role in the educational field. Moreover, this professional is qualified for the care of pregnant women ${ }^{(10)}$.

The reports demonstrated misinformation of mothers regarding the process of parturition. In some cases, they had difficulty to recognize the signs of early labor, as well as clinical changes that needed health care. In this regard, it is known that levels of maternal and infant deaths are still high in Brazil. Most of the times, such occurrences are considered preventable and can be prevented with improved care during prenatal, delivery and newborn care, always ensuring the timely access of the mother and the newborn to highly qualified health services ${ }^{(11)}$.

By the way, Ministry of Health of Brazil, seeking alternatives to improve care, established the Program for Humanization of Prenatal and Birth, with the goal to reduce maternal and child mortality rates ${ }^{(12)}$. Thus, municipalities were assigned as responsible for the coverage and for the quality of prenatal care, for care to delivery and to the postpartum and for neonatal care. For this, a network of relationships based on ethical principles, which may ensure autonomy, sharing knowledge with the pregnant woman and her family, is required ${ }^{(13)}$.

Despite this, actions and programs developed by the Ministry of Health for many years have still major challenges to overcome, regarding the quality of care. There are points related to comprehensive health care, such as psychological, emotional and cultural aspects, which involve assistance that in most cases is not yet properly exploited. In a study conducted in British hospitals, there were differences in paternal involvement during pregnancy and childbirth, depending on some maternal characteristics, such as primiparity, white skin color, women with higher education, and unplanned pregnancy. Thus, it is important that health professionals have a wide view in order to recognize that some women may have less social support, and they need more support from professionals, both in the care of the newborn, and to 
listen to their new experiences ${ }^{(14)}$.

This study has reasserted that the right of woman to be accompanied during labor and birth by a person of their social circle, even as a practice backed by law since 2005 , is still unknown to most of women. Therefore, its implementation in care practices in health services depends on the motivation and commitment of professionals to abandon inappropriate practices that have no evidence of benefit.

This was also found in a randomized clinical trial with 21 participants, where only five women had the support of a companion of their social circle ${ }^{(15)}$. These results indicate that the presence of a companion contributes to the increase of spontaneous vaginal delivery, as well as to reduce the need for intrapartum analgesia and dissatisfaction/negative perception of the experience of giving birth.

The adoption of good practices during labor to help the mother in relieving the pain, as in satisfaction with the experience of giving birth, were implemented by the Stork Network, which advocates the humane care based on scientific evidence as recommended by the World Health Organization Health since 1996. Among the stimulated non-invasive technologies are: the partner's presence, respect for culturally significant practices, stimulating ambulation, the pregnant woman's movement during labor, food, spray bath and immersion, permanence of the newborn close to the mother whenever possible, encouragement of breastfeeding immediately after delivery, among others ${ }^{(16)}$. We realize in this study that women who knew these practices had received prenatal monitoring with nurses and/or resident obstetrical nurses, or sought hospital care during pregnancy.

Such strategies reinforce the incentive to abandon unnecessary practices often used in many services, as well as setting limits for some technologies and obstetric interventions such as cesarean delivery without proper indication, induction of labor by oxytocics, amniotomy, continuous electronic monitoring and routine administration of analgesia and anesthesia during childbirth.
Procedures such as episiotomies and use of exogenous oxytocin are less common when there is concern about the humanization of care for women during childbirth. Thus, the use of a less invasive assistance helps efficiently the evolution of vaginal delivery and contributes to respect the sexual and reproductive rights of women ${ }^{(17)}$.

The Ministry of Health uses strategies in an attempt to change the model of assistance, such as the stimulation of the training and the inclusion of obstetric nurses in practical scenarios, especially in the center of vaginal delivery. These professionals seek to use obstetrical practices aimed at humanization of labor and birth, but also to implement non-pharmacological methods for pain relief ${ }^{(18)}$.

In this study, we observed that women who had follow-up of nurses and/or residents in obstetric nursing during pregnancy and childbirth felt confident and prepared for the experience of childbirth and with the care of newborn due to the instructions they received. It is noteworthy that this professional category sees childbirth as a physiological process, respecting the physical and psychological integrity of women, and also welcome and value the pregnant woman as a being with needs that underlie the biological field ${ }^{(18)}$.

In this study, educational activities developed by nurses and/or residents in obstetrical nursing made possible the reception and safe hosting for the future newborn. Depending on how one is born and is welcomed in the world, relations and behavior of human beings with themselves and with this world can be defined ${ }^{(19)}$.

The educational dimension permeates the entire process of care, mostly performed by nurses, opening great opportunities for discussion between common sense and science. Thus, health education carried out in this scenario showed a very transformative approach, because it acts as a strategy in the change of paradigm in relation to birth in our society and, in a very direct way, opens different social perspectives to drive and experience the process of birth. 


\section{Conclusion}

Health education activities conducted during prenatal care by nurses and/or residents in obstetrical nursing contributed to changes in the perception of women in relation to the process of parturition. Due to the work of these professionals, participants had the opportunity to enhance their knowledge about reproductive and human rights, as well as about the changes in the process of pregnancy and puerperium and about physiology of their bodies, giving new meaning and rescuing their autonomy as protagonists in process of labor and birth. Consequently, they became more active and sought assistance in accordance with ministerial recommendations.

Although we have a traditional obstetrical model, we observe a social movement for humanization aimed at a dignified and safe care to women and newborns. The formation of obstetric nurses contributes positively to this movement. However, there is still a long way ahead, for which the expansion and recognition of the role of obstetrical nurses, as well as their inclusion in health services and professional legitimization, are essential.

\section{Collaborations}

Quadros JS and Reis TLR contributed to the conception and design, analysis and interpretation of data, article writing and final approval of the version to be published. Colomé JS contributed to critical review of the intellectual content and final approval of the version to be published.

\section{References}

1. Guerreiro EM, Rodrigues DP, Queiroz AB, Ferreira MA. Educação em saúde no ciclo gravídicopuerperal: sentidos atribuídos por puérperas. Rev Bras Enferm. 2014; 67(1):13-21.

2. Duarte SJ, Borges AP, Arruda GL. Ações de enfermagem na educação em saúde no pré-natal: relato de experiência de um projeto de extensão da Universidade Federal do Mato Grosso. Rev Enferm Cent 0 Min. 2011; 1(2):277-82.
3. Zampieri MF, Gregório VR, Custódio ZA, Regis MI, Brasil C. Processo educativo com gestantes e casais grávidos: possibilidade para transformação e reflexão da realidade. Texto Contexto Enferm. 2010; 19(4):719-27.

4. Gomes ML, Moura MA, Souza IE. Obstetrical practice by nurses in institutional childbirth: a possibility for emancipatory knowledge. Texto Contexto Enferm. 2013; 22(3):763-71.

5. Progianti JM, Costa RF. Práticas educativas desenvolvidas por enfermeiras: repercussões sobre vivências de mulheres na gestação e no parto. Rev Bras Enferm. 2012; 65(2):257-63.

6. Balaskas J. Parto ativo: guia prático para o parto natural. Tradução de Adailton Salvatore Meira. São Paulo: Ground; 2012.

7. Ministério da Saúde (BR). Secretaria de Ciências, Tecnologia e Insumos Estratégicos. Diretrizes de Atençãoà Gestante: a operação cesariana. Relatório de recomendações [Internet]. 2015 [citado 2015 mai 25]. Disponível em: http://conitec.gov.br/ images/Consultas/Relatorios/2015/Relatorio_ PCDTCesariana_CP.pdf

8. Minayo MC. O desafio do conhecimento: pesquisa qualitativa em saúde. São Paulo: Hucitec; 2012.

9. Polit DF, Beck CT, Hungler BP. Fundamentos de pesquisa em enfermagem: avaliação de evidências para a prática de enfermagem. Porto Alegre: Artmed; 2011.

10. Santos RL, Prestes M, Meincke SM, Soares MC, Corrêa AC, Alves CN. Atenção no pré-natal de baixo risco na ótica de puérperas. Rev Enferm UFSM. 2015; 5(4):628-37.

11. Cabral FB, Hirt LM, Van der Sand IC. Prenatal care from puerperal women's point of view: from medicalization to the fragmentation of care. Rev Esc Enferm USP. 2013; 47(2):281-7.

12. Ministério da Saúde (BR). Portaria GM/MS no $569 /$ GM, de $1^{\text {o }}$ de junho de 2000, que institui o Programa de Humanização no Pré-natal e Nascimento [Internet]. 2000 [citado 2015 mai 25]. Disponível em: http://bvsms.saude.gov.br/ bvs/saudelegis/gm/2000/prt0569_01_06_2000_ rep.html

13. Barbieri A, Fonseca LM, Ceron MI, Fedosse E. Análise da atenção pré-natal na percepção de puérperas. Distúrb Comum. 2012; 24(1):29-39. 
14. Redshaw M, Henderson J. Fathers' engagement in pregnancy and childbirth: evidence from a national survey. BMC Pregnancy Childbirth [Internet]. 2013 [cited 2016 Mar 13]; 13:70. Available from: https://archive.org/stream/ pubmed-PMC3607858/PMC3607858-14712393-13-0\#page/n0/mode/2up

15. Hodnett ED, Gates S, Hofmeyr GJ, Sakala C, Weston J. Continuous support for women during childbirth. Cochrane Database Syst Rev. 2011; (2):CD003766.

16. Nascimento NM, Progianti JM, Novoa RI, Oliveira TR,Vargens OM. Tecnologias não invasivas de cuidado no parto realizadas por enfermeiras: a percepção de mulheres. Esc Anna Nery. 2010; 14(3):456-61.
17. Salge AK, Lôbo SF, Siqueira KM, Silva RC, Guimarães JV. Prática da episiotomia e fatores maternos e neonatais relacionados. Rev Eletr Enf [periódico na Internet]. 2012 [citado 2015 mai 25]; 14(4):779-85. Disponível em: https://www. fen.ufg.br/fen_revista/v14/n4/pdf/v14n4a05. pdf

18. Silva AL, Nascimento ER, Coelho EA. Nurses practices to promote dignity, participation and empowerment of women in natural childbirth. Esc Anna Nery. 2015; 19(3):424-31.

19. Leboyer F. Nascer sorrindo. São Paulo: Brasiliense; 2011. 